University of Nebraska - Lincoln

DigitalCommons@University of Nebraska - Lincoln

\title{
Effect of sulfur content in wet or dry distillers grains fed at several inclusions on cattle growth performance, ruminal parameters, and hydrogen sulfide
}

\author{
J. O. Sarturi \\ University of Nebraska-Lincoln \\ Galen E. Erickson \\ University of Nebraska-Lincoln, gerickson4@unl.edu \\ Terry Klopfenstein \\ Universitiy of Nebraska-Lincoln, tklopfenstein1@unl.edu \\ Judson Vasconcelos \\ University of Nebraska-Lincoln, jvasconcelos2@unl.edu \\ William A. Griffin \\ University of Nebraska-Lincoln, wgriffin2@unl.edu \\ See next page for additional authors
}

Follow this and additional works at: https://digitalcommons.unl.edu/animalscifacpub

Sarturi, J. O.; Erickson, Galen E.; Klopfenstein, Terry; Vasconcelos, Judson; Griffin, William A.; Rolfe, Kelsey; Benton, Joshua R.; and Bremer, Virgil R., "Effect of sulfur content in wet or dry distillers grains fed at several inclusions on cattle growth performance, ruminal parameters, and hydrogen sulfide" (2013). Faculty Papers and Publications in Animal Science. 788.

https://digitalcommons.unl.edu/animalscifacpub/788

This Article is brought to you for free and open access by the Animal Science Department at DigitalCommons@University of Nebraska - Lincoln. It has been accepted for inclusion in Faculty Papers and Publications in Animal Science by an authorized administrator of DigitalCommons@University of Nebraska - Lincoln. 


\section{Authors}

J. O. Sarturi, Galen E. Erickson, Terry Klopfenstein, Judson Vasconcelos, William A. Griffin, Kelsey Rolfe, Joshua R. Benton, and Virgil R. Bremer 


\title{
Effect of sulfur content in wet or dry distillers grains fed at several inclusions on cattle growth performance, ruminal parameters, and hydrogen sulfide ${ }^{1}$
}

\author{
J. O. Sarturi,* G. E. Erickson, ${ }^{2}$ T. J. Klopfenstein,* J. T. Vasconcelos,* \\ W. A. Griffin, * K. M. Rolfe, * J. R. Benton,* and V. R. Bremer* \\ *Department of Animal Science, University of Nebraska-Lincoln, Lincoln 68583
}

\begin{abstract}
Effects of $\mathrm{S}$ from wet or dry distillers grains with solubles (DGS) containing 0.82 or $1.16 \% \mathrm{~S}$ on animal growth performance, carcass characteristics, apparent total tract digestibility, and ruminal parameters were evaluated. In Exp. 1, crossbred beef steers $(n=120$; $345 \pm 34 \mathrm{~kg} \mathrm{BW})$ were individually fed ad libitum using Calan gates. Treatments were applied as a $2 \times 2 \times 3+$ 1 factorial treatment arrangement with factors of DGS type (wet or dry), S content in DGS (0.82 or $1.16 \%$ DM basis), and DGS inclusion (20, 30, and 40\%, DM basis), as well as a corn control diet (no DGS). In Exp. 2, ruminally cannulated crossbred beef steers $(n=6 ; 381 \pm 31 \mathrm{~kg}$ BW) were assigned to 1 of 5 diets in a $5 \times 6$ unbalanced Latin Square design and fed ad libitum through five 14-d periods. A $2 \times 2+1$ factorial treatment arrangement was used with the factors of DGS type and $\mathrm{S}$ content in DGS (similar to Exp. 1). Inclusion of DGS was 40\%, except for a MATCH diet containing wet 1.16\% S DGS included at 31.4\% (DM basis). Intake of DM decreased linearly $(P<0.01)$ and quadratically $(P<0.01)$ for steers fed wet and dry DGS that was $1.16 \% \mathrm{~S}$, respectively. In addition,
\end{abstract}

steers fed dry DGS consumed 9\% more DM $(P<0.01)$ than those fed wet. Gain decreased linearly $(P=0.02)$ when wet $1.16 \% \mathrm{~S}$ DGS increased in the diet, representing a $12 \%$ drop in ADG between the Control and $40 \%$ DGS inclusion. A quadratic $(P=0.02)$ improvement in G:F was observed for steers fed wet DGS compared with dry, regardless of S content $(P=0.52)$. Feeding diets with wet $1.16 \% \mathrm{~S}$ DGS linearly decreased $(P=0.03) \mathrm{HCW}$. In Exp. 2, molar proportion of propionate declined $(P=$ $0.01) 9 \%$ and A:P ratio tended $(P=0.13)$ to be greater when 1.16 compared with $0.82 \% \mathrm{~S}$ DGS was fed. Apparent total tract DMD was not affected $(P>0.16)$ and only subtle changes $(P<0.01)$ in ruminal $\mathrm{pH}$ parameters were observed. Greater $(P=0.02)$ ruminal $\mathrm{H}_{2} \mathrm{~S}$ concentration for steers fed wet compared with dry DGS was observed, while $1.16 \% \mathrm{~S}$ DGS tended $(P=0.12)$ to produce greater ruminal $\mathrm{H}_{2} \mathrm{~S}$ than $0.82 \% \mathrm{~S}$. Sulfur in wet DGS appears to be more prone to be converted to ruminal $\mathrm{H}_{2} \mathrm{~S}$, because feeding $1.16 \% \mathrm{~S}$ as wet DGS had a greater impact on $\mathrm{ADG}, \mathrm{DMI}$, and ruminal $\mathrm{H}_{2} \mathrm{~S}$ compared with dry DGS.

Key words: distillers grains, feedlot cattle, hydrogen sulfide, sulfur

\section{INTRODUCTION}

Excess $\mathrm{S}$ in ruminant diets can be detrimental to animal health due to ruminal hydrogen sulfide $\left(\mathrm{H}_{2} \mathrm{~S}\right)$ production and subsequent toxicity, resulting in clinical signs of polioencephalomalacia (PEM); (Gooneratne et al., 1989; Gould et al., 1997; Gould, 1998).

\footnotetext{
${ }^{1}$ A contribution of the University of Nebraska Agricultural Research Division, supported in part by funds provided through the Hatch Act.

${ }^{2}$ Corresponding author: gerickson4@unl.edu

Received July 4, 2012.

Accepted July 14, 2013.
}

However, before animals show clinical symptoms of PEM, or even if they never show signs of the disease, cattle growth performance can decrease (Thompson et al., 1972; Bolsen et al., 1973; Zinn et al., 1997). Studies that evaluated levels of $\mathrm{S}$ in ruminant diets commonly used inorganic sources of $\mathrm{S}$, such as ammonium sulfate (Spears et al., 2011; Bolsen et al., 1973; Zinn et al., 1997), calcium sulfate (Qi et al., 1993), sulfuric acid (Uwituze et al., 2011ab), elemental S (Thompson et al., 1972; Pendlum et al., 1976), or water sulfates (Loneragan et al., 2001) without changing other components in the formulation. However, as with other nu- 
trients in the diet, $\mathrm{S}$ effects on cattle growth performance can vary depending on $\mathrm{S}$ source and profile of ruminal fermentation. As a result, the effects of S-containing ingredients such as distillers grains with solubles (DGS) on animal growth performance may be over- or underestimated. The apparent feeding value of dry DGS is lower compared with wet in cattle finishing diets (Klopfenstein et al., 2008) and the difference may be due to nutrient availability or S availability in wet or dry DGS. Therefore, the objective of this study was to evaluate the effects of $\mathrm{S}$ from wet or dry DGS containing 0.82 or $1.16 \% \mathrm{~S}$ on finishing performance, carcass characteristics, apparent total tract digestibility and ruminal parameters, as well as ruminal hydrogen sulfide $\left(\mathbf{H}_{2} \mathbf{S}\right)$ concentration in cattle.

\section{MATERIALS AND METHODS}

All experimental protocols were previously approved by the University of Nebraska Lincoln Institutional Animal Care and Use Committee (IACUC).

\section{Experiment 1}

Crossbred beef steers $(n=120 ; 345 \pm 34 \mathrm{~kg} \mathrm{BW})$ previously used in a 110-d growth experiment, were individually fed and adapted to a Calan gate system. Steers were allocated by BW in an unbalanced $2 \times 2 \times 3+1$ randomized block design. Following a 5-d limit feeding period ( $2 \%$ BW; $50 \%$ wet corn gluten feed and 50\% bromegrass hay), cattle were weighed on three consecutive days, and stratified by BW based on $\mathrm{d}-1$ and 0 , while average of the $3 \mathrm{~d}$ was used as initial BW for growth performance measurements. Nine steers were assigned randomly to each of the 12 treatments, and 12 steers were fed a Control diet. Cattle were implanted on $\mathrm{d} 1$ with Component TE-IS (Elanco Animal Health, Greenfield, IN) and on d 77 with Component TE-S (Elanco Animal Health), and fed from June 12 to October 12, 2009 (151 d). Cattle were adapted to a high-grain finishing diet over approximately $20 \mathrm{~d}$ by increasing intake (starting with $6.5 \mathrm{~kg}$ and increasing $0.25 \mathrm{~kg} / \mathrm{d}$ until ad libitum). Co-products were obtained from two dry mill ethanol plants from the same company as either wet or dry DGS, and one plant provided greater S content in DGS than the other (Table 1). Treatments (Table 2) were applied as a $2 \times 2 \times 3+1$ factorial treatment arrangement with factors of co-product type (wet or dry DGS), S concentration $(0.82$ or $1.16 \% \mathrm{~S}$ DM basis in the DGS), and DGS inclusion (20, 30, and 40\% DM basis). A control (CON) diet containing a 60:40 ratio of high-moisture and dry-rolled corn (no DGS) was also fed. As levels of co-product inclusion were applied, the 4 high (40\%) inclusion and CON diets were mixed daily, using Roto mix feed trucks. The CON diet was
Table 1. Nutritional composition of wet and dry distillers grains with solubles (DGS) used in Exp. 1 and 2

\begin{tabular}{|c|c|c|c|c|}
\hline \multirow[b]{2}{*}{ Variables $^{1}$} & \multicolumn{2}{|c|}{ DGS with $0.82 \% \mathrm{~S}$} & \multicolumn{2}{|c|}{ DGS with $1.16 \% \mathrm{~S}$} \\
\hline & Dry & Wet & Dry & Wet \\
\hline $\mathrm{DM}, \%$ as-is & 89.6 & 31.2 & 91.6 & 33.5 \\
\hline $\mathrm{CP}, \% \mathrm{DM}$ & 26.5 & 23.9 & 30.3 & 28.1 \\
\hline Fat, $\% \mathrm{DM}$ & 11.4 & 13.4 & 11.2 & 13.6 \\
\hline NDF, \% DM & 30.4 & 23.8 & 24.6 & 20.2 \\
\hline $\mathrm{S}, \% \mathrm{DM}$ & 0.82 & 0.82 & 1.16 & 1.17 \\
\hline ARPS, ${ }^{2} \%$ total $\mathrm{S}$ & 64.3 & 64.3 & 74.8 & 74.8 \\
\hline
\end{tabular}

${ }^{1}$ Analyzed nutritional composition, except for ARPS.

${ }^{2}$ Adjusted ruminal protein S. Calculated assuming S content in ingredients follows same ruminal kinetics of undegradable intake protein, and any other extra inorganic source of S is $100 \%$ available for ruminal reduction to sulfide. This calculation does not account for ruminal $\mathrm{S}$ that is incorporated into microbial biomass.

mixed at feeding time with the $40 \%$ inclusion of each respective type of co-product to prepare the lower (20 and 30\% DM basis) inclusion diets. A blend (60:40 DM basis) of high-moisture and dry-rolled corn was replaced as DGS increased in diets. Diets and individual ingredients were sampled weekly. Steers were fed individually ad libitum once daily in the morning. Bunks were evaluated before feeding and the amount offered adjusted daily to $103 \%$ (DM basis) consumed. Refusals were removed weekly, weighed and subsampled. Dry matter intakes were calculated from DM offered subtracting DM refused. Final BW was calculated from $\mathrm{HCW}$ assuming a $62 \%$ dressing percentage. Therefore, the adjusted final BW was used to calculate ADG and G:F. Cattle were shipped to a commercial packing plant (Greater Omaha, Omaha, NE) where HCW measurement was taken during the harvest day, whereas 12th-rib fat and LM area were measured through a digital camera device (USDA personnel) after a 48-h chill.

\section{Experiment 2}

Ruminally cannulated crossbred beef steers $(n=6$; $381 \pm 31 \mathrm{~kg} \mathrm{BW})$ previously used in a 42-d adaptation trial were assigned to 1 of 5 treatments. A $5 \times 6$ unbalanced Latin square design ( 6 steers and 5 diets) was used. Steers were fed once daily ad libitum through 5 periods $(14 \mathrm{~d}$ each) totaling $70 \mathrm{~d}$. Treatments were arranged as a $2 \times 2+1$ factorial, with factors being type (wet or dry DGS included at $40 \%$ of diet DM), S concentration ( 0.82 and $1.16 \%$ in the DGS, DM basis), and a diet (MATCH) containing wet $1.16 \% \mathrm{~S}$ DGS provided at $31.4 \%$ of diet $\mathrm{DM}$ to match the same total dietary $\mathrm{S}$ as provided by the wet $0.82 \% \mathrm{~S}$ DGS treatment fed at $40 \%$ inclusion (Table $3)$. Including the MATCH treatment allows for comparison of the two wet DGS sources at the same dietary S 
Table 2. Dietary treatments and chemical composition of diets containing wet or dry DGS, ${ }^{1}$ with 1.16 or $0.82 \% \mathrm{~S}$ content in DGS, and subsequent levels of inclusion in Exp. 1

\begin{tabular}{|c|c|c|c|c|c|c|c|}
\hline \multirow[b]{2}{*}{ Ingredients, \% DM } & \multirow[b]{2}{*}{ Control } & \multicolumn{3}{|c|}{ Dry DGS } & \multicolumn{3}{|c|}{ Wet DGS } \\
\hline & & $20 \%$ & $30 \%$ & $40 \%$ & $20 \%$ & $30 \%$ & $40 \%$ \\
\hline Dry DGS & - & 20 & 30 & 40 & - & - & - \\
\hline High-moisture corn & 48 & 36 & 30 & 24 & 36 & 30 & 24 \\
\hline Dry-rolled corn & 32 & 24 & 20 & 16 & 24 & 20 & 16 \\
\hline Corn silage & 15 & 15 & 15 & 15 & 15 & 15 & 15 \\
\hline \multicolumn{8}{|c|}{ Low-S diets analyzed nutritional composition, \% DM } \\
\hline $\mathrm{CP}$ & 13.1 & 14.4 & 14.5 & 16.1 & 13.9 & 13.8 & 15.1 \\
\hline Fat & 4.0 & 5.5 & 6.3 & 7.0 & 5.9 & 6.9 & 7.8 \\
\hline $\mathrm{NDF}$ & 14.9 & 19.3 & 21.5 & 23.7 & 18.0 & 19.5 & 21.0 \\
\hline S & 0.13 & 0.26 & 0.33 & 0.40 & 0.26 & 0.33 & 0.40 \\
\hline ARPS $^{3}$ & 0.06 & 0.16 & 0.20 & 0.25 & 0.16 & 0.20 & 0.25 \\
\hline \multicolumn{8}{|c|}{ High-S diets analyzed nutritional composition, \% DM } \\
\hline ARPS $^{3}$ & - & 0.22 & 0.30 & 0.38 & 0.22 & 0.30 & 0.38 \\
\hline
\end{tabular}

${ }^{1} \mathrm{DGS}=$ distillers grains with solubles containing 0.82 or $1.16 \% \mathrm{~S}$ (DM basis).

${ }^{2}$ Supplement $=$ There were 3 supplements for all 13 diets: one for Control treatment, one for $20 \%$ DGS inclusion, and one for 30 and $40 \%$ DGS inclusion diets. All supplements were formulated to provide (diet DM basis): $33 \mathrm{mg} / \mathrm{kg}$ of monensin; $9.9 \mathrm{mg} / \mathrm{kg}$ of tylosin; $13.8 \mathrm{mg} / \mathrm{kg}$ of thiamine; 4500,900 , and 1.12 IU/kg vitamin ADE, respectively; $60 \mathrm{mg} / \mathrm{kg}$ of Zn; $40 \mathrm{mg} / \mathrm{kg}$ of Mn; $50 \mathrm{mg} / \mathrm{kg} \mathrm{Fe} ; 7.5 \mathrm{mg} / \mathrm{kg}$ of Cu; $1 \mathrm{mg} / \mathrm{kg}$ of I; $0.5 \mathrm{mg} / \mathrm{kg}$ of Co; $3 \mathrm{~g} / \mathrm{kg}$ of NaCl; $1250 \mathrm{mg} /$ $\mathrm{kg}$ of tallow; and $17.5 \mathrm{~g} / \mathrm{kg}$ of limestone. Additionally, Control diet supplement provided $11.4 \mathrm{~g} / \mathrm{kg}$ soybean meal (47\%), $12.5 \mathrm{~g} / \mathrm{kg}$ of urea, and $3.3 \mathrm{~g} / \mathrm{kg}$ of KCl; and supplement fed to $20 \%$ DGS diets provided $5.3 \mathrm{~g} / \mathrm{kg}$ of urea.

${ }^{3} \mathrm{ARPS}=$ Adjusted ruminal protein $\mathrm{S}$. Calculated assuming $\mathrm{S}$ content in ingredients follows same ruminal kinetics of undegradable intake protein, and any other extra inorganic source of S is $100 \%$ available for ruminal reduction to sulfide. This calculation does not account for ruminal $\mathrm{S}$ that is incorporated into microbial biomass.

Table 3. Dietary treatments and chemical composition of diets containing wet or dry distillers grains with solubles (DGS) with 1.16 or $0.82 \% \mathrm{~S}$ content in DGS in Exp. 2

\begin{tabular}{|c|c|c|c|c|c|}
\hline \multirow{2}{*}{$\begin{array}{l}\text { Ingredients, } \\
\% \mathrm{DM}\end{array}$} & \multicolumn{2}{|c|}{$0.82 \% \mathrm{~S} \mathrm{DGS}^{1}$} & \multicolumn{2}{|c|}{$1.16 \%$ S DGS } & \multirow{2}{*}{$\frac{\mathrm{MATCH}^{2}}{\text { Wet }}$} \\
\hline & Dry & Wet & Dry & Wet & \\
\hline Dry DGS & 40 & - & 40 & - & - \\
\hline Wet DGS & - & 40 & - & 40 & 31.45 \\
\hline High-moisture corn & 24 & 24 & 24 & 24 & 29.13 \\
\hline Dry-rolled corn & 16 & 16 & 16 & 16 & 19.42 \\
\hline Corn silage & 15 & 15 & 15 & 15 & 15 \\
\hline Supplement ${ }^{3}$ & 5 & 5 & 5 & 5 & 5 \\
\hline \multicolumn{6}{|c|}{ Diet analyzed nutritional composition, \% DM } \\
\hline $\mathrm{CP}$ & 16.1 & 15.1 & 17.7 & 16.9 & 15.6 \\
\hline Fat & 7.0 & 7.8 & 6.9 & 7.6 & 6.4 \\
\hline $\mathrm{NDF}$ & 23.7 & 21.0 & 21.4 & 20.0 & 19.6 \\
\hline $\mathrm{S}$ & 0.40 & 0.40 & 0.54 & 0.55 & 0.40 \\
\hline ARPS $^{4}$ & 0.25 & 0.25 & 0.38 & 0.38 & 0.28 \\
\hline
\end{tabular}

${ }^{1} \mathrm{DGS}=$ distillers grains with solubles.

${ }^{2}$ MATCH: Diet containing wet $1.16 \%$ DGS in amount to equal S content in diet containing $0.82 \% \mathrm{~S}$ DGS.

${ }^{3}$ Supplement was formulated to provide (diet DM basis): $33 \mathrm{mg} / \mathrm{kg}$ of monensin; $9.9 \mathrm{mg} / \mathrm{kg}$ of tylosin; $13.8 \mathrm{mg} / \mathrm{kg}$ of thiamine; 4500,900 , and 1.12 IU/kg vitamin ADE, respectively; $60 \mathrm{mg} / \mathrm{kg}$ of $\mathrm{Zn} ; 40 \mathrm{mg} / \mathrm{kg}$ of Mn; $50 \mathrm{mg} /$ $\mathrm{kg} \mathrm{Fe} ; 7.5 \mathrm{mg} / \mathrm{kg}$ of Cu; $1 \mathrm{mg} / \mathrm{kg}$ of I; $0.5 \mathrm{mg} / \mathrm{kg}$ of Co; $3 \mathrm{~g} / \mathrm{kg}$ of NaCl; 1250 $\mathrm{mg} / \mathrm{kg}$ of tallow; and $17.5 \mathrm{~g} / \mathrm{kg}$ of limestone.

${ }^{4}$ ARPS $=$ Adjusted ruminal protein S. Calculated assuming S content in ingredients follows same ruminal kinetics of undegradable intake protein, and any other extra inorganic source of S is $100 \%$ available for ruminal reduction to sulfide. This calculation does not account for ruminal $\mathrm{S}$ that is incorporated into microbial biomass. concentration. The two wet DGS sources differ in S concentration. All periods contained $7 \mathrm{~d}$ for adaptation and $7 \mathrm{~d}$ for data collection. Intakes were calculated based on DM offered after subtracting DM refused, and analyzed for the last $7 \mathrm{~d}$ of each period. On $\mathrm{d} 8, \mathrm{pH}$ probes (DASCOR, Escondido, CA) were calibrated and adjusted to record ruminal $\mathrm{pH}$ every minute, and introduced through the cannula into the rumen (saccus ventralis) $7 \mathrm{~d}$ before the end of every period, and removed on $\mathrm{d} 1$ of the following period before feeding time. Ruminal gas samples were collected on $\mathrm{d} 12,13$, and 14 of each period, once daily $8 \mathrm{~h}$ after feeding, through devices inserted in the ruminal cannula (to avoid gas exchange with the environment during the gas collection) before feeding on $\mathrm{d} 12$. A $30-\mathrm{mL}$ plastic syringe coupled to the adapted ruminal cannula was used to pull ruminal gas. The first aliquot of gas was discharged, while the next subsequent 6 aliquots were injected $(5-\mathrm{mL}$ aliquots) inside serum bottles (30$\mathrm{mL}$ glass bottle with a rubber stopper and metal clasp preset with $5 \mathrm{~mL}$ of distilled water; $\mathrm{pH} 8 \pm 0.05$ ). After collection, gas samples and standards were mixed with reagents $(\mathrm{N}, \mathrm{N}$-dimethyl-p-phenylenediamine sulfate and ferric chloride) as described by Kung et al. (1998), and ruminal $\mathrm{H}_{2} \mathrm{~S}$ concentration analyzed with a spectrophotometer at $670 \mathrm{~nm}$ (Spectra, Carson, CA). At the end of each period (d 14), the adapted ruminal cannula plugs 
were replaced by normal plugs, and all the components were cleaned and stored for subsequent periods. On d 14 , ruminal fluid was collected through a manual vacuum pump at 8,13 , and $22 \mathrm{~h}$ after feeding and samples were frozen $\left(-20^{\circ} \mathrm{C}\right)$ immediately for VFA analysis. To analyze VFA in ruminal fluid, samples were thawed and centrifuged $\left(5000 \times \mathrm{g}, 10 \mathrm{~min}, 4^{\circ} \mathrm{C}\right)$. Two milliliters of the supernatant was treated (deproteinized) with $0.5 \mathrm{~mL}$ of $25 \%$ metaphosphoric acid containing 2-ethylbutyrate $(0.2913 \mathrm{~g}$ in $100 \mathrm{~mL}$; internal standard; Erwin et al., 1961). Individual VFA were analyzed in triplicate utilizing gas chromatography (Hewlett-Packard, Avondale, PA). Chromium oxide ( $7.5 \mathrm{~g}$ in gel capsules) was added into the rumen twice daily throughout the entire experiment and spot fecal samples were collected twice daily on the last $5 \mathrm{~d}$ of each period to estimate fecal output. Feces were composited across days and used to estimate apparent total tract DM digestibility (DMD).

In both Exp. 1 and 2, ingredient samples were collected weekly. In Exp. 1 an overall composite of the samples was analyzed, whereas in Exp. 2 samples were analyzed by period. Samples were initially dried in a $60^{\circ} \mathrm{C}$ forced-air oven for $48 \mathrm{~h}$, except for wet co-products which were freeze-dried. All dry samples were ground through a 1-mm screen (Willey Mill, Thomas Scientific, Swedesboro, NJ) before nutrient analysis. Nitrogen was determined using a LECO nitrogen analyzer (AOAC, 1999; Method 990.03), fat was determined using biphasic solvent extraction (Bremer et al., 2010), S was determined using combustion (LECO, 2010), and NDF was determined using thermo stable amylase and sodium sulfite with dried samples (Van Soest et al., 1991). The DGS was analyzed for NDF in sequence after fat extraction. Adjusted ruminal protein $\mathrm{S}$ (ARPS) was calculated assuming that S from S-amino acids follows the protein kinetics inside the rumen. In this way, undegradable intake protein (UIP) is an indirect method to estimate amount of $\mathrm{S}$ that is not available for ruminal reduction in corn samples, because amino acid profile of protein sources does not change before and after ruminal degradation (Goedeken et al., 1990a, 1990b). This calculation does not account for ruminal S (from other sources besides protein) degraded but assimilated into microbial mass, such as S-amino acids, and therefore not available for ruminal reduction to sulfide. For DGS, S content increases by threefold after starch extraction similar to other nutrients (Klopfenstein et al., 2008). Therefore, S content in corn multiplied by 3 was the fraction assumed to have similar UIP kinetics as corn, and any extra $\mathrm{S}$ in DGS was assumed to be inorganic $\mathrm{S}$ added during the ethanol manufacturing process. The extra $\mathrm{S}$ in DGS was considered $100 \%$ available for ruminal reduction.

\section{Statistical Analysis}

In Exp. 1, animal was considered the experimental units, as steers were individually fed. The factorial evaluation $(3 \times 2 \times 2)$ was analyzed using GLIMMIX procedure of SAS. Orthogonal contrasts between the $\mathrm{CON}$ and other diets were tested for linear and quadratic effects of DGS level with $\mathrm{S}$ concentration and whether wet or dry. Block was considered as a random effect. For Exp. 2, data were also analyzed using the GLIMMIX procedures of SAS. Interaction between $\mathrm{S}$ and type of DGS was tested. If not significant, interactions were removed from the model and the main effects were evaluated. Day was accounted as a repeated measure for ruminal $\mathrm{pH}$ and intake, and time for ruminal VFA data. Covariance structures for all repeated measures were chosen based on smallest Akaike's information criterion and Bayesian information criterion. A single degree-of-freedom contrast was used to compare the MATCH diet with wet $0.82 \%$ S DGS diet. Effects were considered significant at a $P \leq 0.05$, with tendencies declared at $P$-values between 0.05 and 0.15 .

\section{RESULTS AND DISCUSSION}

During both Exp. 1 and 2, there were no animal deaths nor any animals treated for PEM. No clinical symptoms of PEM were observed.

\section{Dry Matter Intake (Experiments 1 and 2)}

In Exp. 1, no interactions between DGS type and $\mathrm{S}$ content $(P=0.76)$ or type and level of DGS inclusion $(P=0.67)$ were observed (Table 4$)$. An interaction $(P<$ $0.01)$ between $\mathrm{S}$ content and DGS inclusion level showed that steers fed DGS with $1.16 \% \mathrm{~S}$ at 30 and $40 \%$ inclusion had lower DMI compared with those fed DGS with $0.82 \% \mathrm{~S}$. A tendency $(P=0.12)$ for a 3 -way interaction (type $\times$ level $\times \mathrm{S}$ concentration) was observed. Intake linearly increased $(P=0.02)$ when dry $0.82 \% \mathrm{~S}$ DGS was included in the diet (Table 5), but DMI was not affected $(P \geq 0.38)$ when wet $0.82 \%$ S DGS was fed (Table 6). When steers were fed DGS with $1.16 \% \mathrm{~S}$, DMI decreased linearly $(P<0.01)$ for wet (Table 6$)$ and quadratically $(P$ $<0.01$ ) for dry DGS (Table 5). However, regardless of $\mathrm{S}$ content, 9\% lower DMI $(P<0.01)$ was observed when wet DGS was fed compared with dry (Table 4). Greater DMI for dry DGS compared with wet DGS may suggest that dry DGS has lower energy content compared with wet DGS, as proposed by Klopfenstein et al. (2008).

In Exp. 2 (Table 7), no interaction $(P=0.21)$ was observed between type of DGS and S content for DMI. Steers fed dry DGS had greater DMI $(P<0.01)$ than steers fed wet DGS. Likewise, steers fed DGS with $0.82 \%$ $\mathrm{S}$ consumed more $(P<0.01)$ than steers fed DGS with 
$1.16 \% \mathrm{~S}$, which is consistent with the DMI observed in Exp. 1, where steers were fed identical diets. Greater $(P<0.01)$ DMI was observed when steers were fed wet $0.82 \% \mathrm{~S}$ DGS at $40 \%$ inclusion compared with wet $1.16 \%$ S DGS at $31.4 \%$ inclusion (MATCH). The MATCH diet also had slightly greater dietary ARPS than wet $0.82 \%$ S DGS diet ( 0.28 vs. $0.25 \%$, respectively; Table 3 ). Compared with dry DGS, wet DGS caused a decrease in DMI presumably due to greater ruminal $\mathrm{H}_{2} \mathrm{~S}$. Wet DGS with increased $\mathrm{S}$ exacerbates the $\mathrm{H}_{2} \mathrm{~S}$ detrimental effect. The results indicate that when wet DGS with $1.16 \% \mathrm{~S}$ is included in the MATCH diet to be iso-S with wet DGS possessing $0.82 \% \mathrm{~S}$, steers fed the MATCH diet ate less $(P<0.01) \mathrm{DM}$ and consumed less $(P<0.01)$ total S. It is noteworthy that MATCH steers consumed DM only up to the amount of ARPS consumed by wet DGS $0.82 \% \mathrm{~S}$ steers. The MATCH DMI appeared to be governed by ARPS and not total S intake. This result may or may not be explained by ruminal $\mathrm{H}_{2} \mathrm{~S}$ concentration. To the contrary, the $\mathrm{H}_{2} \mathrm{~S}$ in the MATCH treatment tended to be less $(P<0.14)$ than for the iso-S wet DGS treatment. However, since ruminal $\mathrm{H}_{2} \mathrm{~S}$ was sampled at only one time point per day, the release of $\mathrm{H}_{2} \mathrm{~S}$ from $0.82 \%$ and $1.16 \%$ wet DGS may have different temporal patterns. One plausible reason for lower intakes is related to corn inclusion differences as MATCH diet had greater corn inclusion ( $8.56 \%$ units) compared with $0.82 \% \mathrm{~S}$ wet DGS diet. However, ruminal acidosis due to greater corn concentration is not supported by ruminal $\mathrm{pH}$ data, because average of ruminal $\mathrm{pH}$ observed for these two diets were not different $(P=0.86)$.

Uwituze et al. (2011a) observed an 11\% decrease in DMI when S in dry-rolled and steamflaked corn-based diets containing 30\% dry DGS was raised from 0.42 to $0.65 \%\left(\mathrm{H}_{2} \mathrm{SO}_{4}\right.$ as supplemental source of $\mathrm{S}$ ) in a metabolism study. Following the same treatments but in a growth performance study, Uwituze et al. (2011b) observed an $8.9 \%$ drop in DMI when steers were fed $0.65 \%$ compared with $0.42 \% \mathrm{~S}$. To accomplish their greater S treatment, DGS (fed at $30 \%$ of diet DM) was enriched with $\mathrm{H}_{2} \mathrm{SO}_{4}$ until its $\mathrm{S}$ concentration reached $1.7 \%$, a value which is uncommon for DGS (Buckner et al., 2008b). In the present studies, DMI decreased 20\% (Exp. 1) and 10\% (Exp. 2) when dry $1.16 \% \mathrm{~S}$ DGS (40\% inclusion) was compared with $0.82 \% \mathrm{~S}$, providing diets containing 0.54 and $0.40 \% \mathrm{~S}$, respectively. Following the same comparison between 1.16 vs. $0.82 \% \mathrm{~S}$, but with wet DGS, DMI decreased 9\% (Exp. 1) and 14\% (Exp. 2), respectively. However, even though 
Table 5. Growth performance of steers fed corn control diet and increasing levels of dry distillers grains with solubles (DGS) with 0.82 or $1.16 \% \mathrm{~S}$ in DGS in Exp. 1

\begin{tabular}{|c|c|c|c|c|c|c|c|c|c|c|c|c|c|c|}
\hline \multirow[b]{3}{*}{ Variables $^{1}$} & \multirow[b]{3}{*}{ Control } & \multirow[b]{3}{*}{ SEM } & \multicolumn{6}{|c|}{$0.82 \% \mathrm{~S}$ in dry DGS } & \multicolumn{6}{|c|}{$1.16 \% \mathrm{~S}$ in dry DGS } \\
\hline & & & \multirow[b]{2}{*}{20} & \multirow[b]{2}{*}{30} & \multirow[b]{2}{*}{40} & \multirow[b]{2}{*}{ SEM } & \multicolumn{2}{|c|}{$P$-values ${ }^{2}$} & \multirow[b]{2}{*}{20} & \multirow[b]{2}{*}{30} & \multirow[b]{2}{*}{40} & \multirow[b]{2}{*}{ SEM } & \multicolumn{2}{|c|}{$P$-values } \\
\hline & & & & & & & Lin. & Quad. & & & & & Lin & Quad. \\
\hline \multicolumn{15}{|l|}{ Body weight, kg } \\
\hline Initial & 346 & 7.5 & 348 & 347 & 346 & 8.8 & 0.97 & 0.80 & 342 & 351 & 341 & 8.7 & 0.86 & 0.82 \\
\hline Final & 601 & 8.9 & 607 & 611 & 624 & 10.4 & 0.10 & 0.56 & 608 & 605 & 581 & 10.3 & 0.26 & 0.09 \\
\hline \multicolumn{15}{|l|}{ Daily intake } \\
\hline Total S, g & 14.4 & 1.1 & 29.9 & 38.6 & 49.0 & 1.3 & $<0.01$ & 0.15 & 38.3 & 48.4 & 53.6 & 1.3 & $<0.01$ & $<0.01$ \\
\hline ARPS, $g$ & 6.8 & 0.7 & 17.5 & 23.4 & 30.4 & 0.9 & $<0.01$ & 0.20 & 25.7 & 33.8 & 38.3 & 0.8 & $<0.01$ & $<0.01$ \\
\hline $\mathrm{ADG}, \mathrm{kg}$ & 1.69 & 0.06 & 1.74 & 1.76 & 1.85 & 0.09 & 0.10 & 0.56 & 1.74 & 1.72 & 1.56 & 0.07 & 0.26 & 0.10 \\
\hline $\mathrm{G}: \mathrm{F}$ & 0.152 & 0.004 & 0.151 & 0.151 & 0.151 & 0.005 & 0.83 & 0.88 & 0.151 & 0.153 & 0.157 & 0.005 & 0.52 & 0.47 \\
\hline \multicolumn{15}{|c|}{ Carcass characteristics } \\
\hline
\end{tabular}

${ }^{1}$ Final BW was adjusted from $\mathrm{HCW}$ using a common dressing of $62 \%$; ARPS = Adjusted ruminal protein S. Calculated assuming S content in ingredients follows same ruminal kinetics of undegradable intake protein, and any other extra inorganic source of $\mathrm{S}$ is $100 \%$ available for ruminal reduction to sulfide. This calculation does not account for ruminal $\mathrm{S}$ that is incorporated into microbial biomass.

${ }^{2} P$-values refer to linear or quadratic effects of a contrast between Control diet and increasing levels of dry DGS with 0.82 or $1.16 \% \mathrm{~S}$.

Table 6. Growth performance of steers fed corn control diet and increasing levels of wet distillers grains with solubles (DGS) with 0.82 or $1.16 \% \mathrm{~S}$ in DGS in Exp. 1

\begin{tabular}{|c|c|c|c|c|c|c|c|c|c|c|c|c|c|c|}
\hline \multirow[b]{3}{*}{ Variables $^{1}$} & \multirow[b]{3}{*}{ Control } & \multirow[b]{3}{*}{ SEM } & \multicolumn{6}{|c|}{$0.82 \% \mathrm{~S}$ in wet DGS } & \multicolumn{6}{|c|}{$1.16 \% \mathrm{~S}$ in wet DGS } \\
\hline & & & \multirow[b]{2}{*}{20} & \multirow[b]{2}{*}{30} & \multirow[b]{2}{*}{40} & \multirow[b]{2}{*}{ SEM } & \multicolumn{2}{|c|}{$P$-values ${ }^{2}$} & \multirow[b]{2}{*}{20} & \multirow[b]{2}{*}{30} & \multirow[b]{2}{*}{40} & \multirow[b]{2}{*}{ SEM } & \multicolumn{2}{|c|}{$P$-values } \\
\hline & & & & & & & Lin. & Quad. & & & & & Lin & Quad. \\
\hline Initial & 346 & 7.5 & 339 & 348 & 340 & 8.7 & 0.78 & 0.97 & 335 & 351 & 354 & 8.7 & 0.40 & 0.26 \\
\hline Final & 601 & 8.9 & 621 & 619 & 611 & 10.4 & 0.36 & 0.19 & 603 & 590 & 568 & 10.4 & 0.03 & 0.11 \\
\hline \multicolumn{15}{|l|}{ Daily intake } \\
\hline Total S, g & 14.4 & 1.1 & 27.6 & 35.2 & 43.0 & 1.3 & $<0.01$ & 0.44 & 33.8 & 42.3 & 52.6 & 1.2 & $<0.01$ & 0.97 \\
\hline ARPS, $g$ & 6.8 & 0.7 & 16.1 & 21.3 & 26.6 & 0.8 & $<0.01$ & 0.56 & 22.7 & 29.5 & 37.7 & 0.8 & $<0.01$ & 0.82 \\
\hline $\mathrm{ADG}, \mathrm{kg}$ & 1.69 & 0.06 & 1.83 & 1.81 & 1.75 & 0.07 & 0.39 & 0.16 & 1.71 & 1.62 & 1.47 & 0.07 & 0.02 & 0.09 \\
\hline G:F & 0.152 & 0.004 & 0.172 & 0.170 & 0.163 & 0.005 & 0.05 & 0.01 & 0.167 & 0.166 & 0.152 & 0.005 & 0.66 & $<0.01$ \\
\hline \multicolumn{15}{|c|}{ Carcass characteristics } \\
\hline
\end{tabular}

${ }^{1}$ Final BW was adjusted from HCW using a common dressing of $62 \%$; ARPS = adjusted ruminal protein S. Calculated assuming S content in ingredients follows same ruminal kinetics of undegradable intake protein, and any other extra inorganic source of $\mathrm{S}$ is $100 \%$ available for ruminal reduction to sulfide. This calculation does not account for ruminal $\mathrm{S}$ that is incorporated into microbial biomass.

${ }^{2} P$-values refer to linear or quadratic effects of a contrast between Control diet and increasing levels of wet DGS with 0.82 or $1.16 \% \mathrm{~S}$.

dry DGS diets showed a greater percentage decrease in DMI (on average) when $\mathrm{S}$ concentration increased in the diet, wet DGS diets, regardless of DGS inclusion rate or S concentration, had lower $(P<0.01)$ overall intake compared with dry DGS diets when DGS was included above $20 \%$ of the diet (Table 4 ).
Spears et al. (2011) increased S concentration in ground corn-based (85\%) finishing diets by adding ammonium sulfate and observed a decrease of $17.5 \%$ in DMI when steers were fed $0.46 \% \mathrm{~S}$ compared with 0.13 and $0.31 \% \mathrm{~S}$, which were not different from each other. But DMI was not affected when the same treat- 
Table 7. Intake and ruminal parameters of steers fed diets containing wet or dry distillers grains with solubles (DGS), with 1.16 or $0.82 \% \mathrm{~S}$ content in DGS in Exp. 2

\begin{tabular}{|c|c|c|c|c|c|c|c|c|c|c|}
\hline \multirow[b]{3}{*}{ Variables } & \multirow{2}{*}{\multicolumn{2}{|c|}{$0.82 \% \mathrm{~S}$ DGS }} & \multirow{2}{*}{\multicolumn{2}{|c|}{$1.16 \% \mathrm{~S}$ DGS }} & \multirow{3}{*}{$\begin{array}{c}\text { MATCH }^{1} \\
\text { Wet }\end{array}$} & \multirow[b]{3}{*}{ SEM } & \multicolumn{4}{|c|}{$P$-values } \\
\hline & & & & & & & \multicolumn{2}{|c|}{ Main effects } & \multirow{2}{*}{$\begin{array}{l}\text { Inter. } \\
\mathrm{T} \times \mathrm{S}\end{array}$} & \multirow{2}{*}{$\begin{array}{l}\text { Contrast }^{2} \\
\text { MATCH } \times \\
\text { Low S wet }\end{array}$} \\
\hline & Dry & Wet & Dry & Wet & & & $\begin{array}{l}\text { DGS type } \\
\text { (T) }\end{array}$ & DGS S & & \\
\hline \multicolumn{11}{|l|}{ Daily Intake ${ }^{3}$} \\
\hline Dry matter, $\mathrm{kg}$ & 11.0 & 10 & 9.9 & 8.6 & 8.9 & 0.32 & $<0.01$ & $<0.01$ & 0.21 & $<0.01$ \\
\hline Total S, g & $44^{\mathrm{b}}$ & $38^{\mathrm{c}}$ & $56^{\mathrm{a}}$ & $46^{\mathrm{b}}$ & 35 & 1.6 & $<0.01$ & $<0.01$ & 0.02 & $<0.01$ \\
\hline \multicolumn{11}{|c|}{ Hydrogen sulfide concentration, $\mu \mathrm{mol} / \mathrm{L}$ of ruminal gas } \\
\hline $\mathrm{H}_{2} \mathrm{~S}$ & 0 & 9.2 & 6.2 & 13.0 & 1.9 & 4.5 & 0.02 & 0.12 & 0.68 & 0.14 \\
\hline \multicolumn{11}{|c|}{ In vivo apparent digestibility, $\%$} \\
\hline Dry matter & 69.3 & 70.1 & 69.7 & 66.7 & 72.4 & 1.18 & 0.38 & 0.32 & 0.16 & 0.20 \\
\hline \multicolumn{11}{|l|}{$\mathrm{pH}$ variables } \\
\hline Average & $5.85^{\mathrm{a}}$ & $5.71^{\mathrm{b}}$ & $5.71^{\mathrm{b}}$ & $5.91^{\mathrm{a}}$ & 5.74 & 0.03 & 0.37 & 0.43 & $<0.01$ & 0.86 \\
\hline \multicolumn{11}{|c|}{ Volatile fatty acids, $\mathrm{mMol} / \mathrm{L}$ of total VFA } \\
\hline Total, $\mathrm{mMol} / \mathrm{mL}$ & 116 & 112 & 113 & 120 & 120 & 4.35 & 0.50 & 0.69 & 0.14 & 0.19 \\
\hline Acetate & 55.4 & 54.3 & 54.7 & 55.6 & 56.4 & 2.43 & 0.95 & 0.89 & 0.64 & 0.49 \\
\hline Propionate & 23.9 & 22.9 & 21.9 & 20.7 & 20.2 & 1.21 & 0.18 & 0.01 & 0.92 & 0.23 \\
\hline A:P ratio & 2.49 & 2.41 & 2.60 & 2.72 & 2.83 & 0.24 & 0.88 & 0.13 & 0.47 & 0.16 \\
\hline Butyrate & 14.8 & 16.9 & 17.0 & 18.6 & 18.4 & 1.99 & 0.10 & 0.08 & 0.82 & 0.89 \\
\hline
\end{tabular}

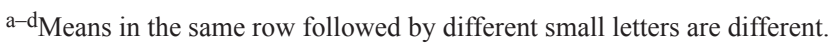

${ }^{1} \mathrm{MATCH}=$ diet containing wet $1.16 \%$ DGS in amount (31.4\% DM basis) to equal $\mathrm{S}$ content in diet containing $0.82 \% \mathrm{~S}$ DGS.

${ }^{2}$ Single degree of freedom contrast comparing $0.82 \% \mathrm{~S}$ wet DGS diet against MATCH diet, since both had equal total dietary S.

${ }^{3}$ ARPS $=$ adjusted ruminal protein S. Calculated assuming S content in ingredients follows same ruminal kinetics of undegradable intake protein, and any other extra inorganic source of $\mathrm{S}$ is $100 \%$ available for ruminal reduction to sulfide. This calculation does not account for ruminal $\mathrm{S}$ that is incorporated into microbial biomass.

${ }^{4}$ Time below pH 5.6 ( $\left.\mathrm{min}\right)$; Area below pH $5.6(\mathrm{~min}$ below $\mathrm{pH} 5.6 \times$ delta $\mathrm{pH})$.

ments were applied to growing diets containing $86 \%$ corn silage. Similarly, Bolsen et al. (1973) observed a 25 to $27 \%$ decrease in DMI for steers fed dry-rolled corn-based diets containing 0.41 compared with 0.14 and $0.20 \% \mathrm{~S}$, by adding ammonium sulfate and removing urea from the diet. In addition, a $13 \%$ decrease in DMI was also observed when yearlings crossbred heifers were fed steam-flaked corn and $\mathrm{S}$ was added (ammonium sulfate) from 0.13 up to $0.25 \%$ in the diet in a growth performance study (Zinn et al., 1997). Predicting the decrease in DMI from total S levels (\% in DM) reported in the studies above (Bolsen et al., 1973; Zinn et al., 1997; Spears et al., 2011), we predict that, for each $0.01 \%$ unit of dietary $\mathrm{S}$ increase above $0.13 \% \mathrm{~S}$, a $0.76 \%$ percentage unit decrease in DMI is expected. Assuming this ratio, when steers were fed the greater $\mathrm{S}$ concentration diets in Exp. $1(0.54 \%)$, and the difference being $0.41(0.54-0.13)$, one would expect a $31 \%$ drop in DMI $(0.76 \times 41)$, which does not agree with the observed decrease in DMI (11\%) in the current study. However, it does not seem appropriate to compare DMI effects of S from inorganic sources (ammo- nium sulfate) against a blend of organic and inorganic S (S-containing ingredients such as dry or wet DGS). In addition, DMI observed from Zinn et al. (1997) cannot be extrapolated, because DGS was not fed and S level in the diet was considerably lower than both current studies. The inconsistency in DMI effects is even more evident in studies evaluating water sulfates. Loneragan et al. (2001) observed that DMI quadratically decreased when sulfates in water corresponded to 0.29 and $0.40 \%$ of $\mathrm{S}$ consumed by steers fed steam-flaked corn-based diets, but only approximately a 3.7\% drop in DMI was observed. Regardless, the mechanisms in which S causes a drop in DMI, the type of ingredient containing S, and the presence or not of DGS appear to be important factors determining the magnitude of the impact of dietary S content on intake.

\section{Gain, Feed Efficiency, and Carcass Characteristics (Experiment 1)}

An interaction between S and dietary level of DGS was observed $(P=0.05)$ for ADG (Table 4$)$. Howev- 
er, ADG was $15 \%$ lower for steers fed wet DGS with $1.16 \% \mathrm{~S}$ at $40 \%$ inclusion compared with wet DGS that was $0.82 \% \mathrm{~S}$ at same inclusion. Gain decreased linearly $(P=0.02)$ when wet $1.16 \% \mathrm{~S}$ DGS increased in the diet (Table 6), which resulted in a 12\% drop in ADG between the CON and $40 \%$ DGS inclusion. Steers fed greater dietary $\mathrm{S}$ from dry DGS tended $(P=0.10)$ to have a quadratic decrease in ADG (Table 5), although no dramatic change in ADG was observed when the CON was compared with the greater $\mathrm{S}$ inclusion of dry DGS diet at $40 \%$ inclusion. In addition, ADG tended to linearly increase $(P=0.10)$ when dry $0.82 \% \mathrm{~S}$ DGS increased in the diet (Table 5), while ADG was not affected $(P=$ 0.16 ) when wet $0.82 \% \mathrm{~S}$ DGS increased in the diet (Table 6). These data suggest that drying either changes ruminal $S$ availability or its potential for conversion to $\mathrm{H}_{2} \mathrm{~S}$ in diets where $\mathrm{S}$ comes from DGS.

No interactions were observed for G:F, but steers fed wet $0.82 \% \mathrm{~S}$ DGS tended $(P=0.10)$ to have better $\mathrm{G}: \mathrm{F}$ compared with those fed wet $1.16 \%$ DGS. A quadratic response $(P=0.02)$ was observed for $\mathrm{G}: \mathrm{F}$ when wet DGS increased in the diet, regardless of $\mathrm{S}$ content $(P=0.52)$, with the best $\mathrm{G}: \mathrm{F}$ at 20 and $30 \%$ inclusions. But steers fed dry DGS at all inclusions showed similar G:F $(P>0.48)$ compared with CON. Consistent with the current study, greater G:F for steers fed wet DGS compared with corn control diets (dry-rolled, steam-flaked, or blend) were also reported in the meta-analysis conducted by Klopfenstein et al. (2008). The similar G:F between corn control and dry DGS diets in the current study was also observed by Buckner et al. (2008a).

No interactions between DGS type, S content, or level of inclusion were observed on carcass characteristics $(P \geq 0.09)$. On average, final BW and HCW of steers fed $1.16 \% \mathrm{~S}$ DGS were $3.5 \%$ lower $(P<0.01)$ compared with those fed $0.82 \%$ S DGS (Table 4$)$. A linear decrease $(P=0.03)$ for both final BW and HCW was observed for steers fed increasing levels of wet $1.16 \%$ S DGS compared with those fed CON (Table 6). Steers fed $1.16 \%$ S DGS had 19\% lower 12th-rib fat $(P<0.01)$ compared with those fed DGS with $0.82 \% \mathrm{~S}$ (Table 4). A linear $(P=0.05)$ decrease on 12 th-rib fat was observed as steers were fed increasing levels of dry $1.16 \% \mathrm{~S}$ DGS compared with those fed the Control diet (Table 5). Dietary treatments did not affect $(P \geq 0.48)$ dressing percentage or LM area $(P \geq 0.10$; Table 4). The HCW and carcass characteristics reflect changes in ADG observed across treatments. Similarly, Uwituze et al. (2011b) did not find an effect of S on G:F, dressing percentage and LM area, but a decrease of $13 \%$ on ADG was observed when $\mathrm{S}$ fed to steers increased from 0.42 to $0.65 \%$ in dry-rolled or steam-flaked corn based diets containing 30\% dry DGS inclusion. A 4\% decrease in final $\mathrm{BW}$ and $\mathrm{HCW}$ were also observed for steers fed the $0.65 \% \mathrm{~S}$ treatment (Uwituze et al., 2011b), which is consistent with a $3.5 \%$ decrease observed in the current study, when $30 \%$ inclusion of DGS that contained $1.16 \% \mathrm{~S}$ was fed compared with $0.82 \% \mathrm{~S}$ DGS; regardless if it was dry or wet. In contrast, 12th-rib fat was not affected in Uwituze et al. (2011b) study. With lower dry DGS inclusion (15\%), Kelzer et al. (2010) also observed a decrease in ADG when steers were fed 0.25 or $0.43 \% \mathrm{~S}$ (calcium sulfate as supplemental source of S) although G:F was also negatively affected by $\mathrm{S}$ concentration in their study.

Effects of $\mathrm{S}$ on gain and carcass characteristics have also been reported in diets with no DGS inclusion. Spears et al. (2011) reported a 20\% drop in ADG when steers were fed ground corn finishing diets in which $\mathrm{S}$ (ammonium sulfate as source of supplemental S) increased from 0.13 to $0.46 \%$, while $\mathrm{G}: \mathrm{F}$, dressing percentage, LM area, and marbling score were not affected. Similarly, Bolsen et al. (1973) observed a decrease in ADG (35\%) and no effects on G:F, as well as carcass grade when steers were fed $0.42 \% \mathrm{~S}$ in dry-rolled cornbased diets compared with 0.14 and $0.20 \%$ (ammonium sulfate as source of supplemental S). However, a lower impact on ADG was observed in the current study when similar total dietary S level $(0.43 \%)$ was fed. At this S level, ADG decreased 3.5\% when steers were fed wet $1.16 \% \mathrm{~S}(30 \%$ inclusion) compared with those fed CON $(0.13 \%$ S), but not when dry $1.16 \%$ S DGS was fed. Zinn et al. (1997) reported a 9\% decrease in ADG when steers were fed steam-flaked corn-based diets with $0.25 \% \mathrm{~S}$ (ammonium sulfate as source of supplemental S) compared with 0.13 or 0.20 . A decrease of $4.3 \%$ in HCW was observed while dressing percentage and marbling score did not change, and 12th-rib fat thickness numerically decreased $23 \%$. However, no differences were observed on ADG and carcass characteristics when similar total $\mathrm{S}$ was fed $(0.26 \%)$ in the current study. When goats where fed $50 \%$ ground peanut hulls and cornstarch, and S was added (calcium sulfate) up to dietary levels of $0.20,0.28$, and $0.38 \% \mathrm{~S}$, ADG increased 23\% at the first level, but dropped $16 \%$ for 0.28 and $0.38 \% \mathrm{~S}$ when compared with the control diet $(0.11 \%$ S; Qi et al., 1993). In the current study, there was no dietary treatment containing $0.20 \% \mathrm{~S}$ to be compared with the corn control diet. However, when S levels were 0.26 and $0.40 \%$ (wet or dry $0.82 \%$ S DGS diets at 20 and $40 \%$ inclusion, respectively), ADG was not affected compared with the corn control diet. Variable data have been reported on growth performance when elemental S was used as S source. When S content was increased from 0.12 to $0.37 \%$ in ground corn diets (Thompson et al., 1972), ADG and DMI dropped 12 and $15.5 \%$, respectively, in only 1 of 3 experiments. In contrast, when the same $\mathrm{S}$ source was used to raise $\mathrm{S}$ 
content in ground corn plus $30 \%$ cottonseed hulls diets from 0.11 to 0.26 and $0.42 \%$, no effects were observed on animal growth performance (Pendlum et al., 1976). On the other hand, improvements in ADG and feed efficiency were observed when steers were fed elemental $\mathrm{S}$ at $0.32 \%$ in dry-rolled corn-based diets compared with $0.14 \% \mathrm{~S}$ corn control (Rumsey, 1978). The absence of negative effects on cattle growth when excess elemental S was fed appears to be related to the lower digestibility (28\%) of this source (Johnson et al., 1970).

There is a lack of information on effects of $\mathrm{S}$ on animal growth performance in diets containing DGS and other organic S containing ingredients. It appears that increasing levels of inorganic sources of $\mathrm{S}$ at feeding time does not characterize well the effects of $\mathrm{S}$ content from DGS on cattle growth performance.

\section{Ruminal $\mathrm{H}_{2} \mathrm{~S}$, S Intake, DM Digestibility, VFA, Ruminal pH (Experiment 2)}

In Exp. 2, no interaction $(P=0.68)$ was observed between type of DGS and $\mathrm{S}$ content for ruminal $\mathrm{H}_{2} \mathrm{~S}$ concentration (Table 7). Steers fed wet DGS had $72 \%$ greater $(P=0.02) \mathrm{H}_{2} \mathrm{~S}$ concentration in ruminal gas cap than steers fed dry DGS. Steers fed $1.16 \%$ S DGS tended $(P=0.12)$ to have greater ruminal $\mathrm{H}_{2} \mathrm{~S}$ concentration compared with DGS that was $0.82 \% \mathrm{~S}$ (Table 7). Diets containing wet DGS appear to provide greater availability of $\mathrm{S}$ for microorganism reduction and subsequent $\mathrm{H}_{2} \mathrm{~S}$ production. This observation is partially supported by the linear decrease in $\operatorname{ADG}(P=0.02) \mathrm{ob}$ served for steers fed wet DGS that was $1.16 \% \mathrm{~S}$ compared with those fed the Control diet, which did not happen when steers were fed dry DGS with $1.16 \% \mathrm{~S}(P$ $=0.10$ ) in Exp. 1 (Table 5). When included at $31.4 \%$ of diet, $1.16 \% \mathrm{~S}$ wet DGS tended $(P=0.14)$ to decrease ruminal $\mathrm{H}_{2} \mathrm{~S}$ concentration compared with steers fed wet $0.82 \%$ S DGS at $40 \%$ inclusion, even though both diets had the same amount of total S (0.40\% DM basis). This comparison suggests that ruminal $\mathrm{H}_{2} \mathrm{~S}$ concentration when steers are fed diets containing DGS may be also influenced by level of DGS inclusion and not just by total amount of $\mathrm{S}$ in the diet. Uwituze et al. (2011b) observed $20 \%$ greater ruminal $\mathrm{H}_{2} \mathrm{~S}$ concentration at 8 and $12 \mathrm{~h}$ postfeeding for steers fed DRC with $30 \%$ dry DGS in diets containing 0.65 compared with $0.42 \% \mathrm{~S}$. They also observed a negative relationship between ruminal $\mathrm{H}_{2} \mathrm{~S}$ concentration and $\mathrm{ADG}$ as $\mathrm{S}$ concentration increased in the diets. Neville et al. (2012) observed a greater ruminal $\mathrm{H}_{2} \mathrm{~S}$ concentration for steers fed diets with $60 \%$ dry DGS compared with 20 and $40 \%$, although excretion of S was also increased for greater inclusions of dry DGS. Dietary treatments evaluating the impact of levels DGS on ruminal $\mathrm{H}_{2} \mathrm{~S}$ may be confounded by levels of starch in the diet. Moreno et al. (2011) showed, in an in vitro incubation, that $\mathrm{H}_{2} \mathrm{~S}$ production increased more dramatically when starch content increased at different $\mathrm{S}$ levels.

Ruminal $\mathrm{H}_{2} \mathrm{~S}$ is a product of $\mathrm{S}$ reduction (Bird, 1972), which is related to PEM cases when excess of $S$ is fed to ruminants (Gould, 1998). Thus it is suggestive that subclinical effects of $\mathrm{H}_{2} \mathrm{~S}$ inhalation by ruminants fed high $\mathrm{S}$ diets might reduce growth rate. However, no effects were observed $(P=0.93)$ when total $\mathrm{S}$ intake was regressed to ADG in Exp. 1. Because ADG decreased linearly only when steers were fed $1.16 \% \mathrm{~S}$ wet DGS compared with those fed Control diet, only wet diets were regressed to ADG, but still no relationship was observed between total S (TS) intake and ADG $(P=$ $0.17)$. Assuming that $S$ availability to ruminal reduction follows the UIP kinetics and all extra $\mathrm{S}$ added in the ethanol industry is readily available for ruminal reduction; an adjusted ruminal protein $\mathrm{S}$ (ARPS) intake can be calculated. A significant $(P=0.04)$ linear relationship was observed when ADG was regressed on ARPS intake, but explained only $6 \%$ of the variation in ADG $(y, \mathrm{~kg}=1.93-0.00881 \times$ ARPS intake, g). In Exp. 2, steers fed dry DGS with $1.16 \% \mathrm{~S}$ had the greatest $(P$ $<0.01)$ TS and ARPS intake compared with the other treatments (Table 7). However, steers fed dry DGS showed less ruminal $\mathrm{H}_{2} \mathrm{~S}$ concentration compared with those fed wet DGS diets. The ARPS concept was first described by Sarturi et al. (2013). The authors observed that measured ARPS intake (discounting S that was ruminally degraded but recycled into microbial biomass) was able to explain $65 \%$ of the ruminal $\mathrm{H}_{2} \mathrm{~S}$ concentration variation when steers were fed organic, inorganic, or blend (wet DGS) sources of S. Nichols et al. (2013) used the same calculation as the current study to find ARPS coefficients in the diets and observed, in a metaanalysis, that increased levels of dietary ARPS by itself was related to increased PEM incidence. The relationship between PEM and TS was dependent on roughage level in beef cattle finishing diets containing DGS, as was also observed by Vanness et al. (2009). It is important to remember that the ARPS intake calculation assumes the same coefficient of S availability for both wet and dry DGS, which may not be true based on the data presented in the current study. Further investigation is needed to evaluate sources of ingredients containing $\mathrm{S}$ and the relationships between $\mathrm{H}_{2} \mathrm{~S}$ and TS/ARPS intake, as well as a methodology to quantify the amount of $\mathrm{S}$ that is available only for ruminal reduction to $\mathrm{H}_{2} \mathrm{~S}$ (ruminal available $\mathrm{S}$ ) from feedstuffs.

Apparent total tract DM digestibility (DMD) was not affected $(P=0.16)$ by type of DGS (dry or wet) nor DGS S content $(0.82$ or $1.16 \%$ ), averaging $70 \%$ (Table 7). Likewise, Zinn et al. (1997) did not observe 
effects on apparent total tract DMD of Holstein steers fed increased levels of S (up to $0.25 \%$ ) in steam-flaked corn-based diets (ammonium sulfate was the source of supplemental S). Similarly, but with sodium sulfate as source of supplemental S, Boila and Golfman (1991) did not find any effect of S on apparent total tract DMD of Holstein steers fed 0.12 compared with $0.39 \% \mathrm{~S}$ in rolled barley-based diets. In contrast, Uwituze et al. (2011a) observed 5\% units greater apparent total tract DMD for steers fed 0.65 compared with $0.42 \% \mathrm{~S}$ in steam-flaked and dry-rolled corn-based diets containing 30\% dry DGS. Those authors suggested that the increase in digestibility was attributed to a tendency for a drop in DMI when steer were fed $0.65 \% \mathrm{~S}$. However, the change in digestibility is inconsistent with a drop in ADG observed for the greater S treatment in the same comparison in a growth performance study (Uwituze et al., 2011b). Apparent total tract DMD does not explain effects of $\mathrm{S}$ on animal growth performance, suggesting that effects of S may be involving more indirect postabsorptive state characteristics (e.g., $\mathrm{H}_{2} \mathrm{~S}$ after eructation, reinhalation and lung absorption) than availability of nutrients for gastrointestinal digestion and absorption.

Ruminal $\mathrm{pH}$ variables are presented in Table 7 . Probes measuring $\mathrm{pH}$ were recovered $7 \mathrm{~d}$ later from the same position that they were initially placed inside the rumen. An interaction between type of DGS and S content was observed for average ruminal $\mathrm{pH}(P<0.01)$, area $(P<0.01)$, and time $(P<0.01)$ below ruminal $\mathrm{pH}$ 5.6. Steers fed wet $1.16 \% \mathrm{~S}$ and dry $0.82 \% \mathrm{~S}$ DGS diets had greater average $\mathrm{pH}$, and lower time and area below ruminal $\mathrm{pH} 5.6$ compared with wet $0.82 \% \mathrm{~S}$ and dry $1.16 \% \mathrm{~S}$ DGS diets. Variance of ruminal $\mathrm{pH}$ was not affected $(P=0.16)$ by treatment. The lower intake observed for steers fed wet $1.16 \%$ S DGS, in both Exp. 1 and 2, may be related to the greater average ruminal $\mathrm{pH}$, as well as lower time and area below $\mathrm{pH} 5.6$ for this treatment. In this case, lower intake could decrease the amount of fermentable substrate inside the rumen. Conversely, steers fed dry $0.82 \% \mathrm{~S}$ DGS had similar average ruminal $\mathrm{pH}$, although DMI was one of the greatest. The lower energy value in dry compared with wet DGS (Klopfenstein et al., 2008) may explain why DMI was greater for dry DGS yet ruminal $\mathrm{pH}$ was similar to other treatments. In this case, greater intake of dry DGS compared with wet would be necessary to reach same level of substrate available for fermentation, and when this limit was reached similar ruminal $\mathrm{pH}$ was observed. No clear effects of S content in wet or dry DGS were observed on ruminal $\mathrm{pH}$ in the current study. Gould (1998) suggested that ruminal $\mathrm{pH}$ and ruminal $\mathrm{H}_{2} \mathrm{~S}$ concentration may be related, because low $\mathrm{pH}$ favors reduction of $\mathrm{S}$ to $\mathrm{H}_{2} \mathrm{~S}$ in the rumen. There is an equilibrium between dissolved (hydrosulfide is soluble in water and acts as weak acid) and gaseous forms of $\mathrm{H}_{2} \mathrm{~S}(\mathrm{pKa}=6.9$ in 0.01 to $0.1 \mathrm{~mol} / \mathrm{L}$ solutions at $18^{\circ} \mathrm{C}$ ), and ruminal content $\mathrm{pH}$ will have an influence on this balance. Because of lack of effect on ruminal $\mathrm{pH}$ in this study, there is likely little impact of rumen $\mathrm{pH}$ on dissolved versus gaseous $\mathrm{H}_{2} \mathrm{~S}$. Rumsey (1978) observed a decrease in average ruminal $\mathrm{pH}$ when steers were fed 0.63 compared with $0.32 \% \mathrm{~S}$ (elemental S as source of supplemental S). However, Gould et al. (1997) did not observe differences in ruminal $\mathrm{pH}$ from Holstein steers fed $1.8 \%$ sodium sulfate in an experimental induction of PEM in finishing diets, where average ruminal $\mathrm{pH}$ was 6.0 , and $\mathrm{H}_{2} \mathrm{~S}$ in the ruminal gas cap increased 40 times compared with the control animals. Moreover, Zinn et al. (1997) and Thompson et al. (1972) also did not observe changes in ruminal $\mathrm{pH}$ related to $\mathrm{S}$ content in finishing diets, when $\mathrm{S}$ increased from 0.12 to $0.25 \%$ (ammonium sulfate as supplemental source of $S$ ) and 0.12 to $0.37 \%$ (elemental $\mathrm{S}$ as supplemental source of $\mathrm{S}$ ), respectively. Furthermore, Qi et al. (1993) observed a linear increase in ruminal $\mathrm{H}_{2} \mathrm{~S}$ concentration while average ruminal $\mathrm{pH}$ was not affected, when goats were fed diets with 0.11 , $0.20,0.28$, and $0.38 \% \mathrm{~S}$ (calcium sulfate). In contrast, Uwituze et al. (2011a) observed greater average ruminal $\mathrm{pH}$ for steers fed 0.65 compared with $0.42 \% \mathrm{~S}$ in diets with $30 \%$ dry DGS. These authors suggested that greater ammonia and lower VFA concentrations may be responsible for the rise in ruminal $\mathrm{pH}$ in the high $\mathrm{S}$ treatment, although why greater ruminal $\mathrm{H}_{2} \mathrm{~S}$ was also observed along with greater ruminal $\mathrm{pH}$ was not discussed. Ruminal $\mathrm{pH}$ is influenced by several factors other than $\mathrm{S}$ concentration in the diet. As a result, the use of ruminal $\mathrm{pH}$ as a predictor of ruminal $\mathrm{H}_{2} \mathrm{~S}$ concentration or as an indicator of effects of $\mathrm{S}$ content in cattle finishing diets is not appropriate.

No interactions $(P>0.15)$ between type of DGS and S content were observed for VFA parameters in Exp. 2 (Table 7). Steers fed $1.16 \%$ S DGS diets had 9\% lower $(P=0.01)$ propionate molar proportion and tended $(P$ $=0.13)$ to have greater A:P ratio compared with DGS that was $0.82 \% \mathrm{~S}$. Additionally, steers fed identical diets in Exp. 1 (40\% inclusion of $1.16 \%$ S DGS) showed a $15.6 \%$ decrease in $\mathrm{ADG}$, as well as a $14.7 \%$ decrease in DMI compared with steers fed $0.82 \%$ S DGS $(40 \%$ inclusion). Thus, lower propionate molar proportion in diets with $1.16 \%$ S DGS is consistent with the fact that ADG dropped more than the actual drop in DMI. Assuming the difference in $\mathrm{S}$ concentration from 0.82 to $1.16 \%$ in DGS is due to the greater amount of sulfuric acid added during ethanol production, the principal source of sulfide generated in the rumen of these steers would have arisen from sulfate reduction. If electrons are flowing to sulfate reduction, then the hypothesis is that fewer are available to form reduced products, such 
as propionate. Similarly, Uwituze et al. (2011a) observed a $25 \%$ decrease in propionate molar proportion for steers fed 0.65 compared with $0.42 \% \mathrm{~S}$ (sulfuric acid as source of supplemental S) in steam-flaked cornbased diets. Additionally, diets with greater S content had greater A:P ratio, but part of this effect was also due to a $10 \%$ greater acetate molar proportion observed for steers fed $0.65 \% \mathrm{~S}$ in dry-rolled corn diets compared with $0.42 \% \mathrm{~S}$. As mentioned previously, sources of $\mathrm{S}$ impact amount of $\mathrm{S}$ available in the rumen. The $\mathrm{S}$ from DGS is likely not as available for ruminal reduction and thus less likely to change propionate molar proportion. Moreover, if values for ARPS are estimated for Uwituze et al. (2011a b) studies, steers fed $0.65 \% \mathrm{~S}$ were also fed greater ARPS ( 0.49 vs. $0.26 \%)$ compared with those fed $0.42 \% \mathrm{~S}$. These ARPS levels are greater compared with the current studies, where the greatest ARPS diet fed was $0.38 \%$. When inorganic sources of $\mathrm{S}$ were fed in the experiments reported previously, a slight decrease (7 to $10 \%$ ) in acetate molar proportion was also observed, which was not observed in the current study.

Steers fed wet DGS had $11 \%$ greater $(P=0.10)$ butyrate molar proportion compared with those fed dry DGS (Table 7). Butyrate molar proportion was also $10 \%$ greater $(P=0.08)$ for steers fed diets containing DGS with $1.16 \% \mathrm{~S}$ than those fed $0.82 \% \mathrm{~S}$ DGS. Zinn et al. (1997) and Thompson et al. (1972) did not observe any effects of $\mathrm{S}$ on butyrate molar proportion. In contrast, Uwituze et al. (2011a) observed approximately $15 \%$ lower molar proportion of butyrate for steers fed 0.65 compared with $0.42 \% \mathrm{~S}$ in the diet, regardless if fed with steam-flaked or dry-rolled corn-based diets. Butyrate can serve as an important energy source for the ruminant, especially for epithelium cells (Russell, 2002). However, butyrate impact on animal growth performance might not be crucial in this evaluation, since butyrate represented only $15 \%$ of the total VFA molar proportion.

Overall, greater S content in DGS (1.16 compared with $0.82 \%$, DM basis) at $40 \%$ inclusion decreased DMI regardless if fed wet or dry, although steers fed dry DGS consumed more DM compared with steers fed wet DGS. Gain, HCW, and 12th-rib fat decreased more when wet DGS with greater $\mathrm{S}$ content was compared with dry DGS. Regardless of S content, wet DGS improved feed efficiency compared with dry DGS. Sulfur in wet DGS diets appears to be more prone to be converted to ruminal $\mathrm{H}_{2} \mathrm{~S}$, because both animal growth performance and ruminal $\mathrm{H}_{2} \mathrm{~S}$ concentration in dry DGS diets were less affected when compared with corn-based diet. Molar proportion of propionate declined when $1.16 \%$ S DGS was fed at $40 \%$ inclusion. Apparent total tract DMD and ruminal $\mathrm{pH}$ parameters are not good indicators of ruminal metabolism changes induced by $\mathrm{S}$ levels in beef cattle finishing diets. Ruminal $\mathrm{H}_{2} \mathrm{~S}$ gas concentration,
ADG, and DMI were less affected when steers were fed $1.16 \% \mathrm{~S}$ from dry DGS compared with wet, suggesting that $\mathrm{S}$ in dry DGS is less available for reduction to sulfide than is $\mathrm{S}$ in wet DGS.

\section{LITERATURE CITED}

AOAC. 1999. Official method of analysis. 16th ed. Assoc. Off. Anal. Chem, Arlington, VA.

Bird, P. R. 1972. Sulphur metabolism and excretion studies in ruminants. X. Sulphide toxicity in sheep. Aust. J. Biol. Sci. 25:1087-1098.

Boila, R. J., and L. S. Golfman. 1991. Effects of molybdenum and sulfur on digestion by steers. J. Anim. Sci. 69:1626-1635.

Bolsen, K. K., W. Woods, and T. Klopfenstein. 1973. Effect of methionine and ammonium sulfate upon performance of ruminants fed high corn rations. J. Anim. Sci. 36:1186-1190.

Bremer, V. R., C. D. Buckner, A. W. Brown, T. P. Carr, and R. M. Diedrichsen. 2010. Method for lipid and NDF analysis of ethanol byproduct feedstuff. J. Anim. Sci. (E-Suppl. 3):123.

Buckner, C. D., T. L. Mader, G. E. Erickson, S. L. Colgan, D. R. Mark, V. R. Bremer, K. K. Karges, and M. L. Gibson. 2008a. Evaluation of dry distillers grains plus solubles inclusion on performance and economics of finishing beef steers. Prof. Anim. Sci. 24:404-410.

Buckner, C. D., S. J. Vanness, G. E. Erickson, T. J. Klopfenstein, and J. R. Benton. 2008b. Sampling wet distillers grains plus solubles to determine nutrient variability. Beef Cattle Rep. MP 91:126-127.

Erwin, E. S., G. J. Marco, and E. M. Emery. 1961. Volatile fatty acid analyses of blood and rumen fluid by gas chromatography. J. Dairy Sci. 44:1768-1771.

Goedeken, F. K., T. J. Klopfenstein, R. A. Stock, and R. A. Britton. 1990a. Hydrolyzed feather meal as a protein source for growing calves. J. Anim. Sci. 68:2945-2953.

Goedeken, F. K., T. J. Klopfenstein, R. A. Stock, R. A. Britton, and M. H. Sindt. 1990b. Protein value of feather meal for ruminants as affected by blood additions. J. Anim. Sci. 68:2936-2944.

Gooneratne, S. R., A. A. Olkowski, and D. A. Christensen. 1989. Sulfur-induced Polioencephalomalacia in sheep: Some biochemical changes. Can. J. Vet. Res. 53:462-467.

Gould, D. H. 1998. Polioencephalomalacia. J. Anim. Sci. 76:309-314.

Gould, D. H., B. A. Cummings, and D. W. Hamar. 1997. In vivo indicators of pathologic ruminal sulfide production in steers with diet-induced polioencephalomalacia. J. Vet. Diagn. Invest. 9:72-76.

Johnson, W. H., D. Goodrich, and J. C. Meiske. 1970. Appearance in the blood plasma and excretion of ${ }^{35} \mathrm{~S}$ from three chemical forms of sulfur by lambs. J. Anim. Sci. 31:1003-1009.

Kelzer, J. M., T. D. Maddock, T. N. Holt, A. DiCostanzo, G. I. Crawford, and G. C. Lamb. 2010. Effects of supplemental manganese and stress responses in beef cattle fed low and high sulfur finishing diets containing distillers grains plus solubles. J. Anim. Sci. 88(E. Suppl. 2):512. (Abstr.)

Klopfenstein, T. J., G. E. Erickson, and V. R. Bremer. 2008. BOARDINVITED REVIEW: Use of distillers by-products in the beef cattle feeding industry. J. Anim. Sci. 86:1223-1231.

Kung, L., A. O. Hession, and J. P. Bracht. 1998. Inhibition of Sulfate Reduction to Sulfide by 9,10 -Anthraquinone in in vitro ruminal fermentations. J. Dairy Sci. 81:2251-2256.

LECO. 2010. S in plant, feed, grain, and flour using the TruSpec. www.leco.com. Accessed 1 Nov. 2011.

Loneragan, G. H., J. J. Wagner, D. H. Gould, F. B. Garry, and M. A. Thoren. 2001. Effects of water sulfate concentration on performance, water intake, and carcass characteristics of feedlot steers. J. Anim. Sci. 79:2941-2948. 
Moreno, M. R., E. Seitz, G. Crawford, A. DiCostanzo, and M. D. Stern. 2011. In vitro effect of starch and sulfur on rumen gas production and hydrogen sulfide release. J. Anim. Sci. 89(E. Suppl. 2):150. (Abstr.)

Neville, B. W., G. P. Lardy, K. K. Karges, S. R. Eckerman, P. T. Berg, and C. S. Schauer. 2012. Interaction of corn processing and distillers dried grains with solubles on health and performance of steers. J. Anim. Sci. 90:560-567.

Nichols, C. A., V. R. Bremer, A. K. Watson, C. D. Buckner, J. L. Harding, G. E. Erickson, T. J. Klopfenstein, and D. R. Smith. 2013. The effect of sulfur and use of ruminal available sulfur as a model to predict incidence of polioencephalomalacia in feedlot cattle. Bov. Pract. (in press).47(1):47-53.

Pendlum, L. C., J. A. Boling, and N. W. Bradley. 1976. Plasma and ruminal constituents and performance of steers fed different nitrogen sources and concentrations of sulfur. J. Anim. Sci. 43:1307-1314.

Qi, K., C. D. Lu, and F. N. Owens. 1993. Sulfate supplementation of growing goats: Effects on performance, acid-base balance, and nutrient digestibilities. J. Anim. Sci. 71:1579-1587.

Rumsey, T. S. 1978. Effects of dietary sulfur addition and Synovex-S ear implants on feedlot steers fed an all-concentrate finishing ration. J. Anim. Sci. 46:463-477.

Russell, J. B. 2002. Rumen microbiology and its role in ruminant nutrition. http://ars.usda.gov/services/software/download. htm?softwareid=409. (Accessed February 12, 2013).
Sarturi, J. O., G. E. Erickson, T. J. Klopfenstein, K. M. Rolfe, C. D. Buckner, and M. K. Luebbe. 2013. Impact of source of sulfur on ruminal hydrogen sulfide and logic for the ruminal available sulfur for reduction concept. J. Anim. Sci. 91:3352-3359.

Spears, J. W., K. E. Lloyd, and R. S. Fry. 2011. Tolerance of cattle to increased dietary sulfur and effect of dietary cation-anion balance. J. Anim. Sci. 89:2502-2509.

Thompson, L. H., M. B. Wise, R. W. Harvey, and E. R. Barrick. 1972. Starea, urea, and sulfur in beef cattle rations. J. Anim. Sci. 35:474-480.

Uwituze, S., G. L. Parsons, and K. K. Karges. 2011a. Effects of distillers grains with high sulfur concentration on ruminal fermentation and digestibility of finishing diets. J. Anim. Sci. 89:2817-2828.

Uwituze, S., G. L. Parsons, and C. J. Schneider. 2011b. Evaluation of sulfur content of dried distillers grains with solubles in finishing diets based on steam-flaked corn or dry-rolled corn. J. Anim. Sci. 89:2582-2591.

Vanness, S., N. Meyer, T. J. Klopfenstein, and G. E. Erickson. 2009. Feedlot incidences of polio and ruminal hydrogen sulfide levels with varying hay level inclusion. J. Anim. Sci. 87(E. Suppl. 3):123. (Abstr.)

Van Soest, P. J., J. B. Robertson, and B. A. Lewis. 1991. Methods for dietary fiber, neutral detergent fiber, and non-starch polysaccharides in relation to animal nutrition. J. Dairy Sci. 74:3583-3597.

Zinn, R. A., E. Alvarez, M. Mendez, M. Montaño, E. Ramirez, and Y. Shen. 1997. Influence of dietary sulfur concentration on growth performance and digestive function in feedlot cattle. J. Anim. Sci. 75:1723-1728. 